\title{
Effects of protein incorporation on calcium phosphate coating
}

\author{
I.B. Leonor *, C.M. Alves, H.S. Azevedo, R.L. Reis \\ 3B's Research Group - Biomaterials, Biodegradables and Biomimetics, Department of Polymer Engineering, University of Minho, \\ Headquarters of the European Institute of Excellence on Tissue Engineering and Regenerative Medicine, AvePark, Zona Industrial da Gandra, 4806-909 Caldas das Taipas, Guimarães, Portugal \\ IBB - Institute for Biotechnology and Bioengineering, PT Government Associated Laboratory, Braga, Portugal
}

\section{A R T I C L E I N F O}

\section{Article history:}

Received 4 October 2007

Received in revised form 5 August 2008

Accepted 6 August 2008

Available online 12 August 2008

\section{Keywords:}

Biodegradable starch polymer

Biomimetic coating

Calcium-phosphate

Enzymes and proteins

\begin{abstract}
A B S T R A C T
The incorporation of proteins into calcium phosphate ( $\mathrm{Ca}-\mathrm{P}$ ) coatings is expected to alter their properties. The aim of this work is, therefore, to study the effect of protein concentration on the formation of Ca-P film. A biodegradable blend of corn starch/ethylene vinyl alcohol (SEVA-C) was used as substrate and bioactive glass (45S5 Bioglass ${ }^{\circledR}$ ) was used as a nucleating agent. Bovine serum albumin (BSA) and $\alpha$-amylase were added, separately, at a concentration of $0.5,1$, and $5 \mathrm{mg} / \mathrm{mLto}$ simulated body fluid (SBF) solutions, at the nucleation stage.

The incorporation of protein molecules was shown to affect the properties of Ca-P coatings in terms of morphology, composition and crystallinity. Both proteins seem to inhibit in some extent and/or retard the growth of Ca-P nuclei at 0.5 and $5 \mathrm{mg} / \mathrm{mL}$ concentrations. FTIR analyses revealed the presence of phosphate and carbonate groups, confirming the formation of a $\mathrm{Ca}-\mathrm{P}$ layer. The characteristic groups of protein molecules were also detected on the IR spectra, which indicate the efficient incorporation of the proteins into the coatings. When $\alpha$-amylase was added to the SBF solution the production of reducing sugars was detected, proving the retention of enzyme activity. These results suggest the carrier potential of Ca-P coatings for the sustained delivery of other biologically active proteins and consequently with a strong potential for inducing bone tissue regeneration.
\end{abstract}

(C) 2008 Elsevier B.V. All rights reserved.

\section{Introduction}

Design strategies for creating biomimetic materials, that direct the interaction with biological systems, such as the formation of tissue surrounding implants or regeneration within artificial matrices, leads to a new interdisciplinary field which could be called molecular engineering $[1,2]$.

It is well known that the ideal implant for bone should demand good biocompatibility, without the possibility of inflammation or foreign body reactions, and present a surface conductive that will induce osseointegration, regardless of the implantation site [3,4]. For bone replacement, a strong bonding with host bone and a osteoconductive surface are also required. Hydroxyapatite (HA), one of the major constituent of bone [5-7], has been often designated as osseointegrating and/or osteoconductive material [8]. Due to its good biocompatibility [5-7] and efficacy in promoting biointegration for implants in hard [9], this bioactive ceramic has been used in various forms during the last decades.

\footnotetext{
* Corresponding author. 3B's Research Group - Biomaterials, Biodegradables and Biomimetics, Department of Polymer Engineering, University of Minho, Headquarters of the European Institute of Excellence on Tissue Engineering and Regenerative Medicine, AvePark, Zona Industrial da Gandra, 4806-909 Caldas das Taipas, Guimarães, Portugal.

E-mail address: belinha@dep.uminho.pt (I.B. Leonor).
}

Calcium phosphate ( $\mathrm{Ca}-\mathrm{P})$ coatings, produced by biomimetic routes, have shown excellent osteoconductive ability and simultaneously offering an opportunity to incorporate protein molecules without compromising their activity, as they are generated under physiological conditions. Therefore, these Ca-P coatings can be used as a vehicle for the controlled release of biologically active molecules, such as bone growth factors (bone morphogenetic proteins - BMPs and other osteoinductive proteins). With this methodology, bioactive proteins can be directly integrated in the structure of Ca-P coatings, maintaining their conformation close to their native form, and thus improve the functionality of the inorganic layer at the implant interface. For instance, with the plasma-spraying technique for producing Ca-P coatings, no active biomolecules can be added during the processing, due to the extremely high temperatures generated by this coating technique.

Moreover, if this coating is applied on a biodegradable polymer, such combination should also integrate within tissues, and progressively be degraded and fully replaced by bone material.

Several works have been reported [10-23] in the literature investigating the influence of protein incorporation on the formation of $\mathrm{Ca}-\mathrm{P}$ coatings produced by means of using biomimetic routes. It has been demonstrated that using these methologies [12,16,20-24] different proteins can be directly integrated into the structure of $\mathrm{Ca}-$ $P$ coatings and also their activity is retained [21-25], being their release mainly controlled by the dissolution behaviour of the coating 
$[16,17,23,26]$. Specific hydrolytic enzymes could be also incorporated to tailor the degradation kinetics of the substrate, which presents an alternative strategy to control the degradation rate of polymeric biomaterials. Such system would be particularly useful in tissue engineering scaffolding by allowing the growth of new tissue into the degrading construct. This is a completely novel approach to tailor the degradation kinetics of biodegradable biomaterials. On the other hand, the incorporation of protein molecules may alter the properties of the coatings and thus these effects need to be evaluated. Therefore, the main goal in this research work is to study the effect of protein concentration on the formation of a Ca-P film at physiological conditions, aiming to establish optimal protein concentration for their efficient incorporation. These coatings may constitute an effective way to provide osteoconductive as well as osteoinductive properties in a single material. As the Ca-P layer undergoes degradation in vivo, the proteins will be gradually released, which enhances the potential of these coatings to serve as a slow-release carrier system for the delivery of growth factors to the implantation site.

\section{Materials and methods}

\subsection{Materials}

The material used in this study was a biodegradable polymeric blend of corn starch with poly (ethylene-vinyl alcohol) copolymer (50/50 wt.\%), designated as SEVA-C. Conventional injection moulding technology (Klockner-Ferromatik Desma FM20, USA) was used to produce $2 \times 4 \mathrm{~mm}^{2}$ cross-section dumb-bell ASTM tensile samples. Further details on the material processing and respective mechanical properties can be found elsewhere [27-29].

A bioactive glass (45S5 Bioglass ${ }^{\circledR}$ ) with the following composition: $45 \mathrm{SiO}_{2}, 24.5 \mathrm{CaO}, 24.5 \mathrm{Na}_{2} \mathrm{O}$ and $6.0 \mathrm{P}_{2} \mathrm{O}_{5}$ in wt.\%, was supplied by NovaMin Technology (Alachua, Florida, USA). This glass powder was used as precursor for calcium-phosphate film deposition and, by laser scattering analysis (Coulter LS 100 particle size analyser) it was measured the particle size that was lower than $20 \mu \mathrm{m}$.

Bovine serum albumin (BSA, Fraction V) was obtained from Sigma (USA) and $\alpha$-amylase, from Bacillus amyloliquefaciens, was kindly supplied by Genencor International, Inc. (USA).

\subsection{Preparation of Ca-P coatings - adapted biomimetic route}

The procedure used to produce Ca-P coating was based on the methodology previously developed by Kokubo et al. [30] and further adapted by Reis et al. [31,32]. Prior to the coating process, SEVA-C samples were sterilized by ethylene oxide. Bioglass ${ }^{\circledR}$ (45S5) was sterilised by immersion in ethanol solution $(70 \%, \mathrm{v} / \mathrm{v})$ and then dried inside the laminar flow cabinet. Protein and enzyme solutions were reconstituted to a final concentration of $0.5,1$ and $5 \mathrm{mg} / \mathrm{mLin}$ simulated body fluid (SBF) solution ( $\mathrm{pH} 7.4$ ) similar to human plasma regarding ions concentration. SBF and protein solutions were sterilized by filtration $(0.2 \mu \mathrm{m}$ pore). All the subsequent procedures
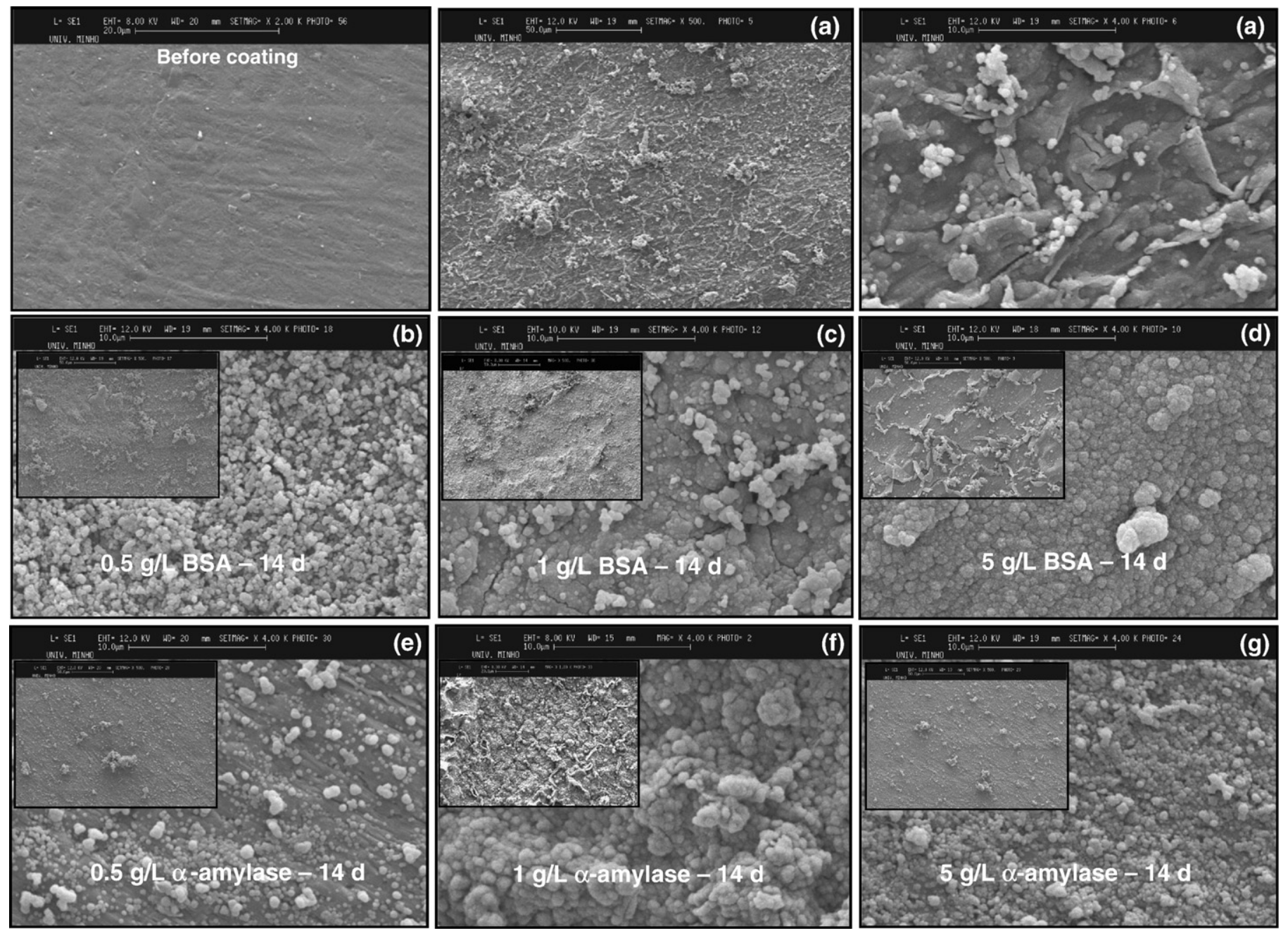

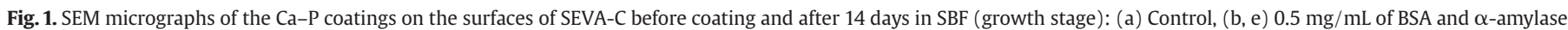
(c, f) $1.0 \mathrm{mg} / \mathrm{mL}$ of BSA and $\alpha$-amylase, and (d, g) $5.0 \mathrm{mg} / \mathrm{mL}$ of BSA and $\alpha$-amylase, added in the nucleation stage. 
were performed under sterile conditions in a vertical flow laminar cabinet to avoid samples and solutions contamination. The SEVA-C samples were rolled on a bed of wet Bioglass ${ }^{\circledR}(45 \mathrm{~S} 5)$ particles and immediately immersed in $15 \mathrm{~mL}$ of $1.0 \mathrm{SBF}$ solution, as control, and in SBF solution containing different concentrations of BSA or $\alpha$-amylase. Incubation time was 7 days at $37{ }^{\circ} \mathrm{C}$ for the $\mathrm{Ca}-\mathrm{P}$ nuclei formation (nucleation stage). Following this period, samples were removed from the incubation solution, immersed in a 1.5 SBF solution for 7 and 14 days in order to allow the growth the Ca-P nuclei (growth stage). After each immersion period, samples were taken from the incubation solution, rinsed with distilled water, dried at room temperature and stored before the surface analysis. Incubation solutions were stored at $4{ }^{\circ} \mathrm{C}$ for ion concentration and enzyme activity determinations.

\subsection{Ca-P coating analysis}

\subsubsection{SEM and EDS}

Ca-P coatings morphology and presence of calcium, phosphorous and silicon elements on the coating surface were analysed, before and after soaking in SBF, by means of scanning electron microscopy (SEM) coupled to energy dispersive spectroscopy (EDS) equipment (Leica Cambridge S360, UK). Previously to EDS and SEM analysis, sample surfaces were carbon coated (Fisons Instruments, Evaporation PSU CA508, UK) and gold sputtered (Fisons Instruments, Sputter Coater SC502, UK), respectively.

\subsubsection{FTIR-ATR}

The chemical structure of the coatings formed on the surface of SEVA-C under the different studied conditions was analysed by Fourier transform infrared spectroscopy with attenuated reflectance (FTIRATR). All spectra were recorded using at least 64 scans and $2 \mathrm{~cm}^{-1}$ resolution in a FTIR spectrophotometer (Perkin-Elmer 1600 Series, USA) with a single reflection ATR system (MKII Golden Gate ${ }^{\mathrm{TM}}$, Specac, UK).

\subsubsection{TF-XRD}

Thin-film X-ray diffraction (TF-XRD, Philips X'Pert MPD, The Netherlands) was used to characterise the crystalline/amorphous nature of the films and to identify any crystalline phases present after the immersion in SBF (results were compared to non immersed controls). The data collection was performed by $2 \theta$ scan method with $1^{\circ}$ as incident beam angle using CuK $\alpha \mathrm{X}$-ray line and a scan speed of $0.05^{\circ} / \mathrm{min}$ in $2 \theta$

\subsection{Solution analysis}

Immersion solutions were analysed in order to determine the concentrations of calcium, phosphorus, silicon and sodium elements as a function of the immersion time. The elemental concentrations were measured by inductively coupled plasma optical emission spectroscopy (ICP-OES, JY 70 plus, Jobin Yvon, France). Duplicate samples were analysed for each condition and immersion time.

In order to assess the presence, or not, of enzyme activity during the coating preparation, the solutions were also analysed. $\alpha$-Amylase is an endo-specific enzyme which catalyses the hydrolysis of $\alpha-1,4-$ glycosidic linkages of starch. The activity of $\alpha$-amylase was monitored by measuring the concentration of reducing sugars liberated into the solution using the dinitrosalicylic acid (DNS) method [33].

\section{Results and discussion}

The effect of proteins on the formation of Ca-P coatings has been subjected to an extensive research [10-23]. Most of these studies aimed to investigate the possible role of plasma proteins on the formation of an apatite layer in vivo, but few had exploited the possibility of incorporating therapeutic agents into $\mathrm{Ca}-\mathrm{P}$ films to develop a delivery system for their sustained release.
Proteins are highly surface-active molecules due to their amphiphilic properties [34]. Hence, they can interact with any encountered interface, generally leading to adsorption of the proteins $[35,36]$, responsible for a range of initial and fate-determining interactions [37]. Albumin, specifically, was the protein selected for this study due to its high concentration in the blood serum, favourable diffusion coefficient and ability to bind other molecules [38,39]. On the other hand, $\alpha$-amylase was also used, being considered as appropriate to study enzymatic properties and due to its ability to interact with starch-based materials [40].

Using a biomimetic coating methodology, it was possible to incorporate biomolecules, such as BSA and $\alpha$-amylase, but considerable

(a)

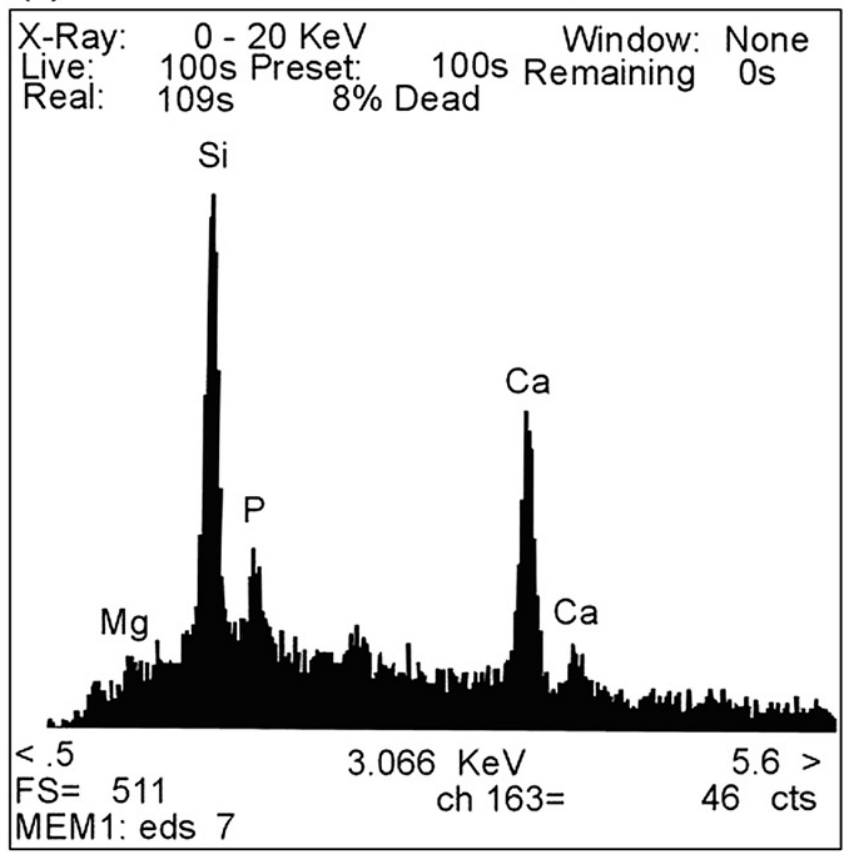

(b)

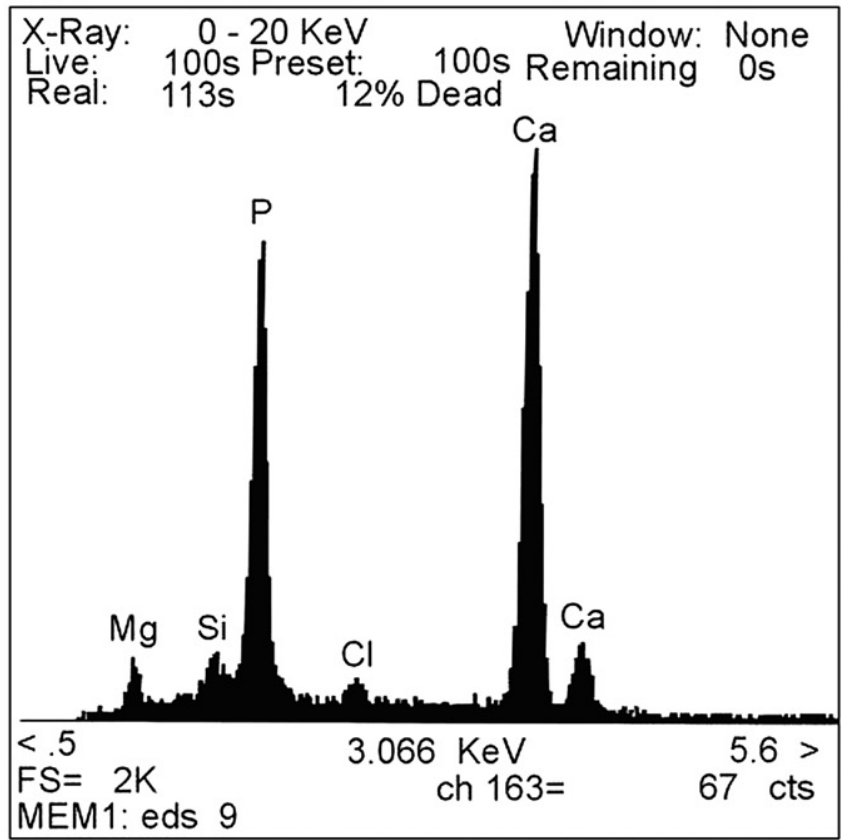

Fig. 2. EDS spectra of the Ca-P coatings on SEVA-C surface after the (a) nucleation stage ( 7 days), and (b) growth stage (14 days) for $0.5 \mathrm{mg} / \mathrm{mL}$ of BSA 
differences were observed. At high concentration $(5 \mathrm{mg} / \mathrm{mL}), \alpha$-amylase presented an inhibitor effect, while BSA had the opposite effect.

Fig. 1 shows the SEM micrographs of the calcium phosphate coatings onto SEVA-C surface before and after soaking in SBF solution for different conditions after 14 days in the growth stage. In the control, it can be observed a uniform Ca-P coating covering all of the SEVA-C substrate.

However, some significant differences were found between the distinct concentrations. At a concentration of $0.5 \mathrm{mg} / \mathrm{mL}$ of BSA, it can be seen the formation of a uniform Ca-P film, but not as dense as the one obtained in the control (see Fig. 1b). Moreover, the Ca-P nuclei growth was delayed and consequently, the film did not grow as function of immersion time.

For $\alpha$-amylase, only the formation of Ca-P nuclei was observed. The additional soaking in SBF did not promote the growth of the Ca-P layer (see Fig. 1e). Quite the opposite was observed when the concentration of the biomolecules was $1 \mathrm{mg} / \mathrm{mL}$ (Fig. 1c and f).

For both proteins, in the first 7 days in the growth stage, the formation of Ca-P film was observed on the SEVA-C surface (data not shown). Furthermore, as the soaking time increased, the $\mathrm{Ca}-\mathrm{P}$ film becomes denser and compact. For higher concentrations, $5 \mathrm{mg} / \mathrm{mL}$, BSA and $\alpha$-amylase induced different effects, as it is shown in Fig. 1d and $g$. In the case of BSA, the film was extremely compact evidencing a finer microstructure at higher magnification: needle-like crystals agglomerated to produce the so-called cauliflower morphology. At higher concentration of $\alpha$-amylase, the growth of Ca-P film was delayed as it can be seen in the Fig. 1g.

EDS analysis (Fig. 2) confirmed the presence of silicon ( $\mathrm{Si}$ ) element as well as the calcium $(\mathrm{Ca})$ and phosphorus $(\mathrm{P})$ elements in the nucleation stage. In the growth stage, the $\mathrm{P}$ and $\mathrm{Ca}$ signals were detected, where their signal intensity significantly increased, indicating in turn density increase of the Ca-P coating. It was also detected the decrease of silicon and the presence of chlorine being the later derived from the SBF solution (Fig. $2 b$ ).

The TF-XRD patterns did not display the main characteristic peaks of hydroxyapatite. In fact, it seems that the formed Ca-P layer is mainly amorphous (data not shown).

The lower intensity of the apatite diffraction peaks indicates that in the nucleation stage a much thinner apatite layer was formed on the specimen surface. This fact was also observed for the other conditions. Studies have been relating the presence of proteins with a lower crystallinity of minerals, such as apatite in the bone $[19,41,42]$.

In Fig. 3, the FTIR-ATR spectrum displays reflectance peaks of phosphate group $\left(\mathrm{PO}_{4}^{3-}\right.$ ) (around $1018 \mathrm{~cm}^{-1}$ ) for the control after 14 days in SBF during the growth stage (please see Fig. 3a).

When $\alpha$-amylase and BSA were added to the SBF solution in the nucleation stage, chemical changes were observed in the IR spectra at $1650 \mathrm{~cm}^{-1}$. This can be ascribed to the amide I band that represents the stretching vibrations of $\mathrm{C}=\mathrm{O}$ bonds in the backbone of the protein (Fig. 3b and c) [43]. In turn, the obtained results could indicate the adsorption of proteins on the surface of the substrate. In the growth stage, the FT-IR spectra show bands centred at $1650 \mathrm{~cm}^{-1}$ that can be also attributed to Amide I (Fig. 3b and c) [43]. For $\alpha$-amylase, these bands can only be observed for $1.0 \mathrm{mg} / \mathrm{mL}$ concentration (see Fig. $3 \mathrm{c}$ ). On the other hand, for 0.5 and $5 \mathrm{mg} / \mathrm{mL}$, the intensities of such bands were not so intense. These results are correlated with the SEM observation, since for 0.5 and $5 \mathrm{mg} / \mathrm{mL}$ of $\alpha$-amylase, it was only observed the formation of $\mathrm{Ca}-\mathrm{P}$ nucleus and a delayed in the growth of the Ca-P film, as it is shown in Fig. 1e and g. Moreover, a small shoulder associated with carbonate substitution at $1418 \mathrm{~cm}^{-1}$ and phosphate band located at $1020 \mathrm{~cm}^{-1}$ respectively, were observed in the collected spectra.

It was found that the adsorption of proteins on the mineral surface can clearly alter the nucleation and growth process, acting as promoters or inhibitors of biomineralisation, depending on the concentration of adsorbed proteins [44]. Combes et al. [44] observed that BSA had two opposite effects on the growth kinetics of octacalcium phosphate (OCP) on type I collagen. At concentrations lower than $10 \mathrm{mg} / \mathrm{mL}$, BSA favoured the growth of OCP, whereas at higher concentrations (up to $60 \mathrm{mg} / \mathrm{mL}$ ) BSA presented an inhibitory effect. In the presence of about $1 \mathrm{mg} / \mathrm{mL}$ of BSA, the OCP growth rate was twice higher than in the absence of BSA.

The variation of $\mathrm{Ca}$ and $\mathrm{P}$ concentrations as a function of immersion time in SBF solution is shown in Fig. 4 for the different concentrations of BSA and $\alpha$-amylase for growth stage.

For the control, an increase in the amount of Si in the SBF can be detected, which is attributed to the dissolution of the bioactive glass (a)

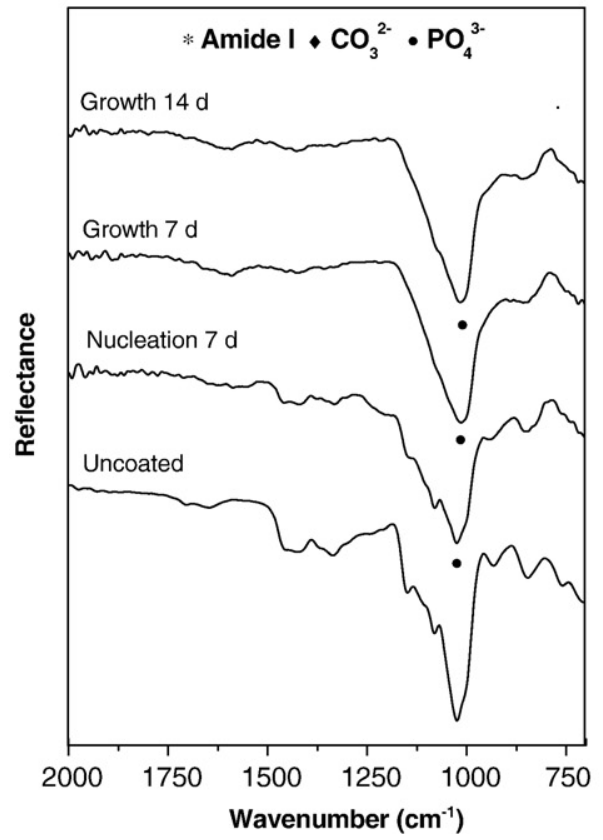

(b)

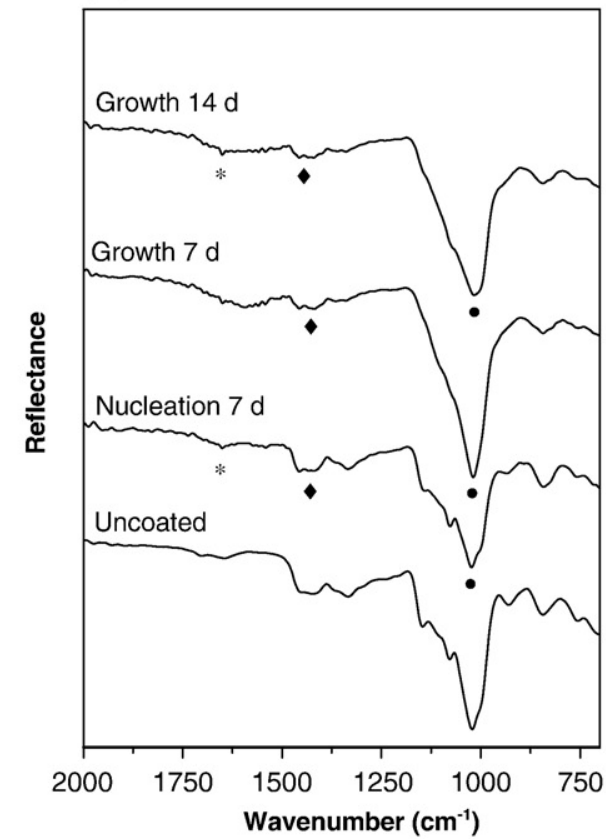

(c)

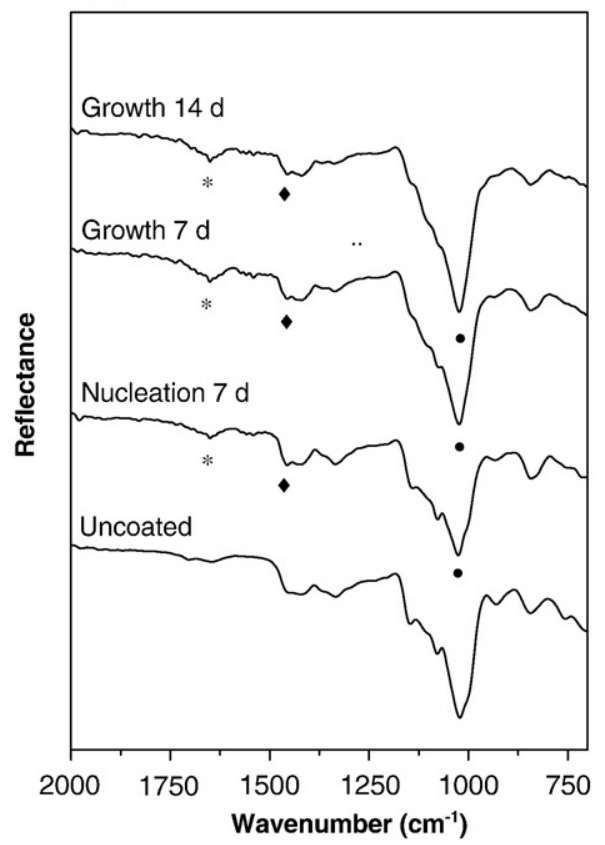

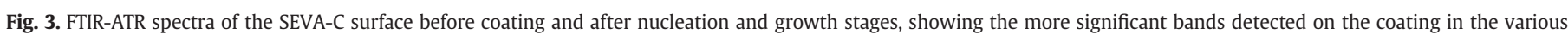
conditions studied: control (a), BSA $1 \mathrm{mg} / \mathrm{mL}$ (b) and $\alpha$-amylase $1 \mathrm{mg} / \mathrm{mL}$ (c). 
(a)

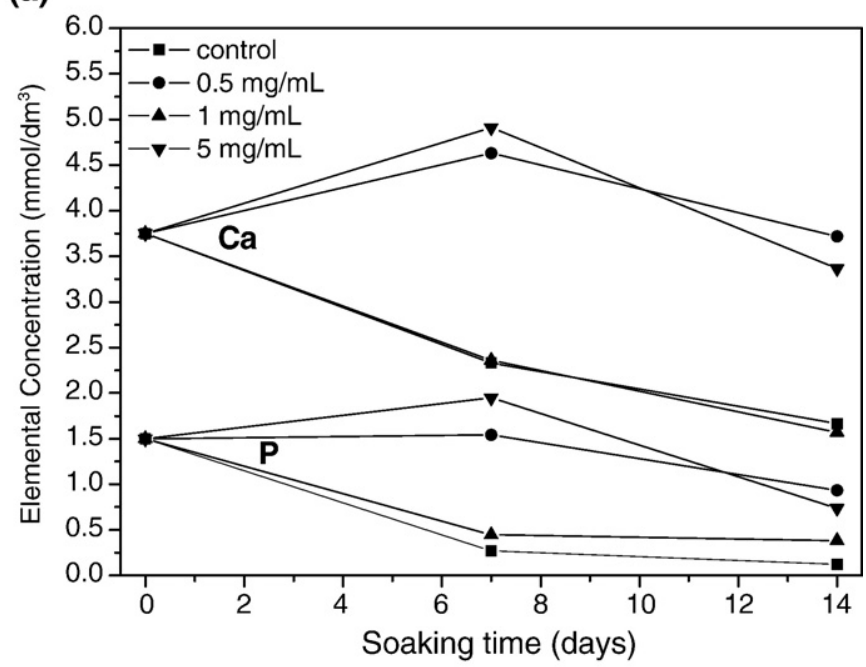

(b)

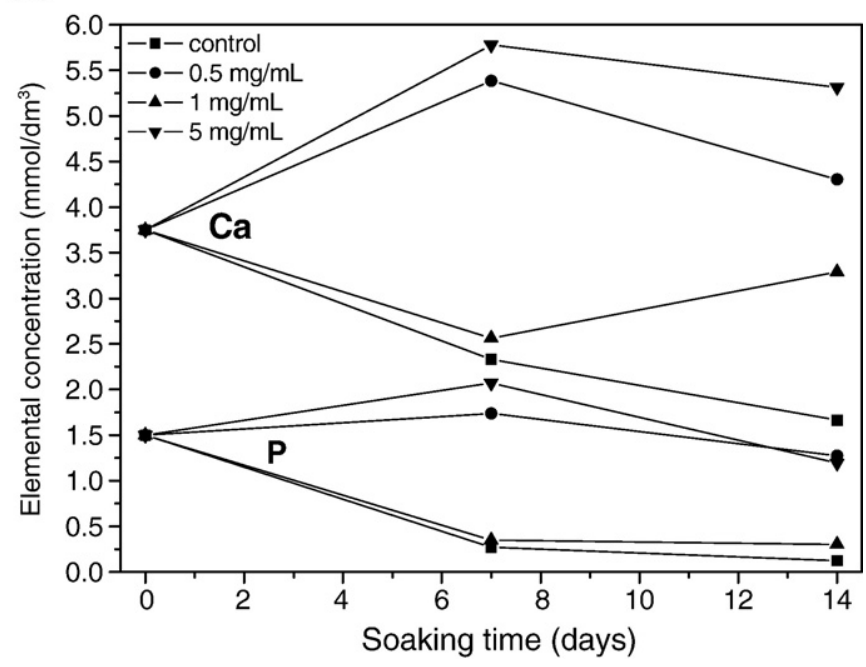

Fig. 4. Evolution of $\mathrm{Ca}$ and $\mathrm{P}$ concentrations in $\mathrm{SBF}$ as function of immersion time in the growth stage for different concentrations of BSA (a) and $\alpha$-amylase (b).

particles. This dissolution provides favourable sites for the formation of $\mathrm{Ca}-\mathrm{P}$ nuclei during the initial period of immersion. Then, as the immersion time increases in the growth stage, $\mathrm{Ca}$ and $\mathrm{P}$ concentrations decreased gradually probably due to the Ca-P formation by consuming the calcium and phosphate ions in SBF.

In the presence of proteins, the amount of Si released to the solution was higher for the concentration $5 \mathrm{mg} / \mathrm{mL}$, which means that the dissolution of the bioactive glass particles was affected by the presence of these proteins.

In the growth stage, there was a large number of $\mathrm{Ca}-\mathrm{P}$ nuclei that induced the spontaneous growth of $\mathrm{Ca}-\mathrm{P}$ film by consuming $\mathrm{Ca}$ and $\mathrm{P}$ ions from 1.5 SBF solution.

For $1 \mathrm{mg} / \mathrm{mL}$ of BSA and $\alpha$-amylase, it can be observed, as the immersion time increases, a gradual decrease in the $\mathrm{Ca}$ and $\mathrm{P}$ concentrations, probably due to the $\mathrm{Ca}-\mathrm{P}$ formation by consuming the calcium and phosphate ions in SBF. In the case of $\alpha$-amylase, there was a slight increase of the Ca concentration after 14 days in SBF. These results might be related with the release of soluble reducing sugars to the solution that may bring associated calcium ions (see Fig. 5).

On the other hand, for the 0.5 and $5 \mathrm{mg} / \mathrm{mL}$ concentrations in both proteins, there was a release of Ca to the solution as well as an increase in $P$ concentration in the first days of immersion in SBF during the growth stage. As it was explained before, this can be due to the release of reducing sugars into the solution, particularly for $5 \mathrm{mg} / \mathrm{mL}$ of $\alpha$ amylase.

The increase of $\mathrm{Ca}$ in the solution leads to the increase of the supersaturation in the SBF solution and as result leads to the formation of $\mathrm{Ca}$-P layer with the subsequent decrease of $\mathrm{Ca}$ and $\mathrm{P}$ concentration in $\mathrm{SBF}$, confirming the growth of Ca-P layer by consuming these ions.

Typical enzyme immobilisation methods require chemical modification of the solid matrix and the covalent attachment of the protein to the matrix. This can result, in many cases, in loss of protein bioactivity. Therefore, it is necessary to select adequate immobilisation techniques to preserve the structure and activity of the proteins.

The hydrolysis of starch is only possible by the pre-adsorption of the enzyme onto the substrate. It is well known that the adsorption of polysaccharide-degrading enzymes to insoluble substrates is a pre-requisite step before catalysis and these enzymes exhibit high affinity and bind specifically to their substrates [45].

$\alpha$-amylase is an endo-specific enzyme, which catalyses the hydrolysis of $\alpha$-1,4-glycosidic linkages of starch to maltose and dextrins, reducing the molecular size of starch. The activity of $\alpha$-amylase can be monitored by measuring the concentration of reducing sugars liberated into the solution. In this particular work, the incorporation of $\alpha$-amylase was used to investigate the possibility of controlling the degradation rate of starch-based polymers.

Fig. 5 shows the concentration of reducing sugars produced in the various stages of the Ca-P formation when different concentrations of $\alpha$-amylase were incorporated at the nucleation stage. It can be seen that after 7 days of incubation in the nucleation period, the production of reducing sugars is enzyme-concentration dependent, which means that for higher enzyme concentration, higher concentration of reducing sugars was detected.

The enzymatic hydrolysis of solid substrates is normally characterised by an enzyme saturation point, at which enzyme concentration, no further increase in the degradation rate is observed when more enzyme is added [46]. This has been attributed to a decrease in the exposed substrate surface as the enzyme molecules saturate the surface and appears to be limiting the progress of catalysis.

In the growth stage, it is also observed the release of reducing sugars, and their concentration increases with incubation time. These findings reveal that $\alpha$-amylase was efficiently incorporated into the coating and remained active. A maximum of enzyme activity was observed, however, when $\alpha$-amylase was incorporated at

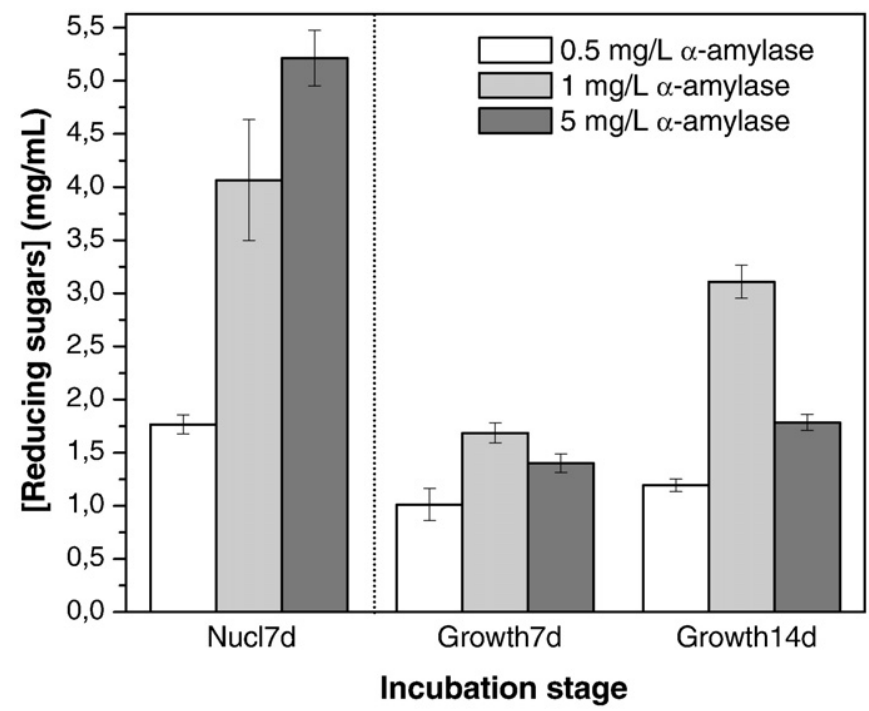

Fig. 5. Concentration of reducing sugars produced at the various stages of the Ca-P formation when different concentrations of $\alpha$-amylase were incorporated at the nucleation period. 
concentration $1 \mathrm{mg} / \mathrm{mL}$. This may indicate that for this concentration higher percentages of enzyme were adsorbed on the polymer surface during the nucleation stage. The efficient incorporation of active $\alpha$ amylase into Ca-P coatings may be used as a method to control the degradation rate of starch-based biomaterials.

The results found in this study are of importance, since they allow the establishment of optimal protein concentrations to be incorporated in the coatings, in terms of incorporation efficiency and the respective effects on the coating properties. In fact, we believe that surfaces coated with biomimetic coatings, into which growth factors or enzymes will be incorporated, hold great potential in bone tissue engineering.

\section{Conclusions}

The supplementation of SBF with different concentration of proteins with distinct properties at the nucleation stage, affected the growth kinetics of a Ca-P layer. Better results were obtained for the concentration of $1 \mathrm{mg} / \mathrm{mL}$, in terms of coating growth and protein incorporation. The incorporation of protein into Ca-P coatings enables the possibility of tailoring their properties and this approach proved to be useful in preserving the activities of enzymes. Herein, indicating the carrier potential of calcium phosphate coatings for the sustained delivery of other bioactive agents. These results enable definitively for the new perspective of adding osteoinductive proteins or growth factors into biomimetic coatings for inducing bone growth on the implant surroundings.

\section{Acknowledgements}

This work was partially supported by Portuguese Foundation for Science and Technology (FCT) and was performed within the framework of the project BIOLEARN (POCTI/CTM/38803/2001) through funds from the POCTI and/or FEDER Programmes. I. B. Leonor thanks FCT for providing her a PhD scholarship (SFRH/BD/9031/2002).

\section{References}

[1] K.E. Healy, A. Rezania, R.A. Stile, Ann. N.Y. Acad. Sci. 875 (1999) 24

[2] K.E. Healy, Curr. Opin. Solid State Mater. Sci. 4 (1999) 381.

[3] D.A. Puleo, A. Nanci, Biomaterials 20 (1999) 2311.

[4] B.S. Chang, C.K. Lee, K.S. Hong, H.J. Youn, H.S. Ryu, S.S. Chung, K.W. Park, Biomaterials 21 (2000) 1291.

[5] A.S. Posner, Clin. Orthop. Relat. Res. 200 (1985) 87.

[6] H. Suh, Yonsei Med. J. 39 (1998) 87.

[7] H. Aoki, Science and medical applications of hydroxyapatite, Takayama Press System Centre Co., Inc, Tokyo, 1991.

[8] L.L. Hench, Biomaterials 19 (1998) 1419.

[9] K.A. Gross, C.C. Berndt, J. Biomed. Mater. Res. 39 (1998) 580.

[10] S. Areva, T. Peltola, E. Sailynoja, K. Laajalehto, M. Linden, J.B. Rosenholm, Chem. Mater. 14 (2002) 1614.
[11] H.S. Azevedo, I.B. Leonor, C.M. Alves, R.J. Goldsmith, R.L. Reis, 7th World Biomaterials Congress, Sydney, 2004, p. 624.

[12] H.S. Azevedo, I.B. Leonor, C.M. Alves, R.L. Reis, Mater. Sci. Eng., C 25 (2005) 169.

[13] B. Feng, J. Chen, X. Zhang, Biomaterials 23 (2002) 2499.

[14] I.B. Leonor, H.S. Azevedo, C.M. Alves, R.L. Reis, in: B. Ben-Nissan, D. Sher, W. Walsh (Eds.), Bioceramics 15, Trans Tech Publications, Zurich, 2003, p. 97.

[15] I.B. Leonor, H.S. Azevedo, I. Pashkuleva, A.L. Oliveira, C.M. Alves, in: R.L. Reis, S Weiner (Eds.), Learning from Nature How to Design New Implantable Biomaterials: from Biomineralization Fundamentals to Biomimetic Materials and Processing Routes, Kluwer Academic Publishers, Dordrecht, 2004, p. 123.

[16] Y. Liu, E.B. Hunziker, N.X. Randall, K. de Groot, P. Layrolle, Biomaterials 24 (2003) 65.

[17] Y.L. Liu, P. Layrolle, J. de Bruijn, C. van Blitterswijk, K. de Groot, J. Biomed. Mater. Res. 57 (2001) 327.

[18] J.W.M. Vehof, J. Mahmood, H. Takita, M.A. van't Hof, Y. Kuboki, P.H.M. Spauwen, J.A Jansen, Plast. Reconstr. Surg. 108 (2001) 434

[19] H.B. Wen, J.R. de Wijn, C.A. van Blitterswijk, K. de Groot, J. Biomed. Mater. Res. 46 (1999) 245.

[20] I.B. Leonor, H.S. Azevedo, C.M. Alves, R.L. Reis, in: R.L. Reis, J.S. Roman (Eds.), Biodegradable Systems in Tissue Engineering and Regenerative Medicine, CRC Press, Boca Raton, USA, 2005, p. 223.

[21] Y. Liu, K. de Groot, E.B. Hunziker, Bone 36 (2005) 745.

[22] Y. Liu, K. de Groot, E.B. Hunziker, Ann. Biomed. Eng. 32 (2004) 398.

[23] Y. Liu, J.P. Li, E.B. Hunziker, K. De Groot, Philos. Trans. R. Soc., A 364 (2006) 233.

[24] L.N. Luong, S.I. Hong, R.J. Patel, M.E. Outslay, D.H. Kohn, Biomaterials 27 (2006) 1175.

[25] Y. Liu, E.B. Hunziker, P. Layrolle, J.D. De Bruijn, K. De Groot, Tissue Eng. 10 (2004) 101.

[26] H.S. Azevedo, I.B. Leonor, R.C. Pereira, R.L. Reis, 30th Annual Meeting of the Society for Biomaterials, Memphis, TN, USA, 2005, p. 302.

[27] R.L. Reis, A.M. Cunha, P.S. Allan, M.J. Bevis, Polym. Adv. Technol. 7 (1996) 784.

[28] R.L. Reis, S.C. Mendes, A.M. Cunha, M.J. Bevis, Polym. Int. 43 (1997) 347.

[29] R.L. Reis, A.M. Cunha, in: K.H.J. Buschow, R.W. Cahn, M.C. Flemings, B. Ilschner, E.J Kramer, S. Mahajan (Eds.), Encyclopedia of materials: science and technology, Elsevier Science, Netherdlands, 2001, p. 8810.

[30] Y. Abe, T. Kokubo, T. Yamamuro, J. Mater. Sci., Mater. Med. 1 (1990) 233.

[31] A.L. Oliveira, C. Elvira, R.L. Reis, B. Vazquez, J. San Roman, J. Mater. Sci., Mater. Med. 10 (1999) 827.

[32] R.L. Reis, A.M. Cunha, M.H. Fernandes, R.N. Correia, J. Mater. Sci., Mater. Med. 8 (1997) 897.

[33] T.K. Ghose, Pure Appl. Chem. 59 (1987) 257.

[34] W. Norde, Adv. Colloid Interface Sci. 25 (1986) 267.

[35] K. Nakanishi, T. Sakiyama, K. Imamura, J. Biosci. Bioeng. 91 (2001) 233.

[36] T. Suzawa, H. Shirahama, Adv. Colloid Interface Sci. 35 (1991) 139.

[37] C. Mannhalter, Sens. Actuators, B, Chem. 11 (1993) 273.

[38] C.R. Jenney, J.M. Anderson, J. Biomed. Mater. Res. 49 (2000) 435.

[39] C. Oehr, Nucl. Instrum. Methods Phys. Res., B Beam Interact. Mater. Atoms 208 (2003) 40 .

[40] H.S. Azevedo, F.M. Gama, R.L. Reis, Biomacromolecules 4 (2003) 1703.

[41] P. Habibovic, F. Barrere, C.A. van Blitterswijk, K. de Groot, P. Layrolle, J. Am. Ceram. Soc. 85 (2002) 517

[42] R.A. Harper, A.S. Posner, Proc. Soc. Exp. Biol. Med. 122 (1966) 137.

[43] J. Xie, C. Riley, M. Kumar, K. Chittur, Biomaterials 23 (2002) 3609.

[44] C. Combes, M. Freche, C. Rey, B. Biscans, J. Mater. Sci. Mater. Med. 10 (1999) 231.

[45] A.B. Boraston, B.W. McLean, J.M. Kormos, M. Alam, N.R. Gilkes, C.A. Haynes, P. Tomme, D.G. Kilburn, R.A.J. Warren, in: H.J. Gilbert, G.J. Davies, B. Henrissat, B. Svenson (Eds.), Recent Advances in Carbohydrate Bioengineering, The Royal Society of Chemistry, Cambridge, 1999, p. 202.

[46] Y.W. Tang, R.S. Labow, J.P. Santerre, Biomaterials 24 (2003) 2003. 